\title{
Political Economy of Forest Tenure Reform Implementation in Nepal: Evolution, Contestation, Outcomes and Challenges
}

\author{
Mani Ram Banjade ${ }^{1}$, Naya S Paudel ${ }^{2}$ and Esther Mwangi ${ }^{3}$ \\ ${ }^{1}$ Center for International Forestry Research, Bogor, Indonesia ${ }^{2}$ ForestAction Nepal, Kathmandu, Nepal \\ ${ }^{3}$ Center for International Forestry Research, Nairobi, Kenya \\ Corresponding author: mrbanjade@gmail.com
}

\section{INTRODUCTION}

Since the 1980s and 1990s, developing countries globally went through forest reforms (Ribot and Larson 2005) aimed at devolving forest rights to customary and other local communities. The reforms emanated either by recognizing the traditional use rights of local communities over forests or by acknowledging the role of local communities in forest conservation whose lives are intricately linked with forest resources. In most part, centralized approaches blatantly failed in conserving forest by exclusionary and coercive measures (Colfer and Capistrano 2005). Data of 50 most forested countries in the world show that the forest area owned or managed by local communities is over 15 per cent and increasing over the last couple of decades, though the rate has slowed down since 2008 (RRI 2014). The reforms to grant rights to local communities involved changes in the national regulatory frameworks, national programs, and institutional arrangements. However, the extent of rights given to these communities differs across the countries and across reform regimes within a country. These reform regimes or types are known in different countries by different names such as community forestry, collaborative forestry, social forestry, customary community forestry, native forestry and joint forest management.

Nepal's forest tenure reforms in relation to granting rights to traditional users of the forests evolved since the 1970s incorporating lessons and accommodating emerging priorities, issues and concerns over time. The experiential learning from initial community forestry modality was scaled out to protected areas as well. Nepal's community based forest management modalities are major departures from the state centric, centralized and expert led approaches to decentralized and community-led forest management. While all the forests in collectivities in Nepal are state owned, several modalities of forest management exist based on the distribution of rights, definition of right holders, institutional arrangements and purpose of forest management. Political, institutional and socio-economic contexts of the emergence of the reforms, power, authority and responsibility of the actors and institutions involved in the reform processes, and goals of such reforms are different across various modalities. Modalities also differ in terms of 'bundle of rights' offered to local communities, legal basis and protection of those rights, roles of different actors in forest management activities, and benefit sharing arrangements. These modalities also emerged in different time frames and have advanced at different pace resulting in considerable variation in outcomes in terms of contribution to livelihoods and changes in forest condition. They also are different in terms of geographical and demographic coverage. For example, while community forestry modality is applied 
across Nepal covering over one fourth of national forest territory, collaborative forestry (the new modality applied in large blocks of forests) is confined to Terai and Inner-Terai regions only. Similarly, while there are about 19000 community forestry groups involving over one third of Nepal's population, leasehold forestry (the modality targeted to the identified poor households) have less than 7000 groups, and collaborative forestry have only 26 groups.

This special issue provides a comprehensive analysis of different forest management modalities, which is key to understanding the different forest tenure types in Nepal. Ten years ago, the special issue of this journal included six modalities of community based forest management (CBFM), namely community forestry, collaborative forestry, leasehold forestry, buffer zone community forestry, integrated conservation and development, and watershed management (Journal of Forest and Livelihood Vol. 6, No. 2, 2007). Major focus was on unpacking the context and process of emergence and evolution of these CBFM modalities and drawing insights from the achievements in meeting specific livelihoods and environmental objectives. Since the publication of that special issue, there have been considerable changes in the local, national and international contexts demanding a fresh assessment of the forest reforms in Nepal.

Since September 2015, Nepal has adopted federated structure of governance, which is a sharp departure from the previous unitary state. This restructuring also has considerable effect on governance across many sectors including forest sector governance. This restructuring offers considerable opportunity in expanding community rights over forests but also poses threats to tenure security. Therefore, issues of rights and tenure security in the changing political landscape deserve more attention. The ongoing forest sector reform process might be much more informed if it takes stock of the insights from the existing forest tenure reforms. Similarly, new issues and discourses have an effect on the existing reform types. The issues of climate change, environmental services and REDD + have emerged since then. In addition, due to environmental concerns of certain discourses, new tenure types emerged namely protection forests and Chure Conservation Zones. Discussion on diverse spectrum of forest tenure systems would be incomplete without including the newly emerged reform types and discussing about community rights and tenure security in the changing context of climate change and environmental services. Therefore, analytical framework is also different in this issue. A total of eight reform types are assessed giving special attention to the principles and indicators of tenure security, namely community forest (CF), collaborative forest management (CFM), buffer zone community forest (BZCF), leasehold forest (LHF), rangeland, chure and private forest. Finally, a paper analyses across different reform types by using the gender lens.

In this introduction paper, we first define concepts such as tenure and forest tenure reform, tenure security and institutions. Then, we offer key principles and indicators of tenure security, which serves as the broad framework for the subsequent papers. Finally, we provide the key features of each paper included in this special issue. 


\section{CONCEPTUAL FRAMEWORK: TENURE SECURITY PRINCIPLES AND INDICATORS}

In this section, we first define the key concepts such as forest tenure reform and tenure security followed by the key principles and indicators of tenure security as a framework for assessing various tenure reform types in Nepal. While tenure has been the central issue in ongoing debate in forest sector governance in Nepal, there is a paucity of comprehensive knowledge about why tenure security is important and in what way this would affect the performance of forest sector governance. Moreover, different stakeholders have different perception of forest tenure; for example, some within government bureaucracy equate forest tenure with land ownership. Similarly, a number of tenure reform types exist that differ in terms of extent of rights granted, protection of rights and socio-economic and ecological focus of the reform; some faring better in some aspects while less effective in other areas. Therefore, it is imperative to critically examine different reform types using the same framework. The principles and indicators of forest tenure security being described below provides that framework.

\section{Tenure and Forest Tenure Reform}

Tenure is related to property rights, which gives an individual or group to have defined rights over the resources. When it comes to natural resources, tenure is defined as 'the social relations and institutions governing access to and use of land and resources' (von Benda Beckman et al. 2006). Forest tenure rights can involve ownership of the forestland, which is considered as the most comprehensive rights over forest resource (FAO 2011). But other rights such as tenancy, agreements and customary practices can also offer rights to access, use and manage forests. These rights are together termed as 'bundle of rights'.

Bundle of rights can be broadly defined as use rights (access and withdrawal) and decision-making rights (management, exclusion and alienation).

Some kind of formal contracts or leases define the extent, modality and duration of exercising these rights. Based on the formalisation status, tenure could be formal, informal, or a combination of both. In terms of right holders, tenure can be termed as individual, group, communal, customary or state.

Tenure includes claims of rights, claimants, authority for monitoring and sanctioning, and mechanism of granting and guaranteeing rights. In relation to forestry, competing and overlapping claims are often seen in practice. Similarly, within the same piece of forestland, multiple claimants might have been enjoying rights for different benefit streams. For example, while a piece of land belongs to a person or community, specific products within the land (e.g. a tree or NTFP) could belong to or used by another person or group.

Tenure reform involves not only change in policies and regulations but also a range of decisions and practices at various levels. Forest tenure reform involves the change in existing forest policy and regulations to be able to offer rights to local communities. The reform can be a massive shift in policies and laws completely overriding the existing one, introducing a new one without replacing the existing one, or change in the operational strategies (Mahoney and Thelen 2010) without a significant change in the existing tenure arrangements. 
At very basic level, the forest tenure reform implementation is largely an enforcement of decisions made at various governance levels. They, in turn, involve a series of decisions (mostly operational) such as clarifying reforms, developing programs and action plans, allocating budget and human resources, making day-to-day operational decisions, making changes in action strategies within the given framework, communicating with various actors at different levels, assessing the existing information and exploring the need and strategies for accessing information, making sense of dynamism (resource, actor landscape, market, etc.) and changing strategies accordingly, and making decisions about incentives. In addition, in case the existing mandates are inadequate to address the new challenges, the reform implementers may need to inform or get additional mandates/ resources from an appropriate level of authority. Similarly, they also need to make decisions related to new knowledge and skills, and required investment (North 2005) as change in the external environment and dynamics/politics of local interventions may demand for new knowledge and skills.

Tenure reform is considered as a dynamic process (Larson et al. 2010a; FAO 2011), demanding a research framework that embraces the dynamics of change. FAO (2011) establishes tenure reform implementation as part of the tenure system that involves policy and regulatory framework, reform implementation arrangements and practices, and policy and legal feedback mechanisms. The performance of reforms is very much tied with the role and performance of corresponding institutions.

\section{Tenure Security as a Framework for Assessing Forest Tenure Regimes}

Tenure security is defined as 'the ability of an individual [or group] to appropriate resources on a continuous basis, free from imposition, dispute or approbation from outside sources' Mwangi and MeinzenDick (2009: 310). Similarly tenure security exists when: 'an individual perceives that he or she has the right...as well as the ability to reap the benefits of labour and capital invested in that land, either in use or upon transfer to another holder' (MigotAdholla and Bruce 1994: 19). Content and legality, duration, protection and assurance of rights are the key domains of tenure security. In terms of the content, the general perception is that the higher the level in bundle of rights hierarchy (Schlager and Ostrom 1992), the better. In terms of alienation rights, private land titles are the most secure property rights. In terms of duration, the more time that the rights are granted, the better secured the rights will be. That means, if we compare across modalities with the same bundle of rights, the more secure right is considered as the one that is granted for a longer time period. Assurance is a kind of guarantee that the rights granted are not expropriated.

The security of rights involves not only the extent of rights granted but also other dimensions such as duration of different rights and risk of losing them (Bruce and Migot-Adholla 1994 cited in Sjaastad and Bromley 2000).

One of the major thrusts of forest tenure reforms has been that each forest tenure regime has offered some rights and benefits to the local people. Therefore, 
an examination of various forest tenure regimes from the framework of tenure security should receive profound attention, in order to have a better understanding about which regimes are faring better in what aspects of tenure security. The following figure includes various aspects of forest tenure and security of rights.

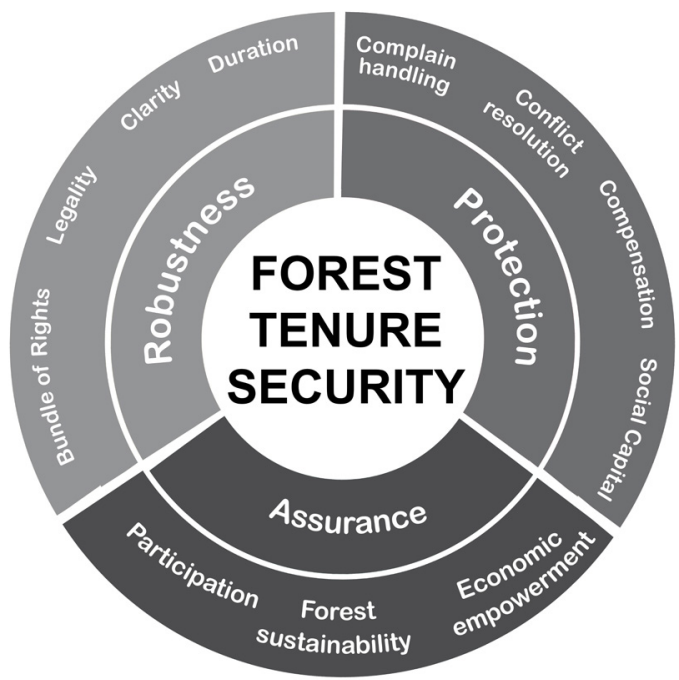

Figure 1: Principles and Indicators of Forest Tenure Security (adapted from Safitri 2015)

The framework includes eleven indicators of tenure security, which can be broadly categorised in three broad principles of tenure security, namely robustness of rights, protection of rights, and assurance of participation and outcomes.

\section{Robustness of Rights}

Robustness of rights refers to 'bundle', legality, clarity and duration of rights granted. Bundle of rights is the extent of rights granted, which can range from access to forest areas for recreation or passing through to other areas, use of forest products and other resources, manage forest, exclude outsiders, to alienation rights. The legality of rights includes legal basis, authority to grant rights, division of authority and responsibility among stakeholders within the same level and at different levels of government, and harmony within the law and among various laws and regulations. Clarity in terms of right holders as the subject of the rights, boundaries of right object, content of rights and procedures to obtain and enforce rights are key for tenure security.

\section{Protection of Rights}

In addition to what rights one gets or who grants what rights on what legal basis, the perception of tenure security also depends on whether safeguards of such rights are in place. In other words, rights protection mechanisms such as complaint handling, conflict resolution and compensation when the rights are abdicated are key to increasing tenure security. When members or groups feel dissatisfied, and when there is a conflict because of overlapping claims over resources and benefits or otherwise, existence of complaint handling and conflict resolution mechanisms respectively would enhance tenure security. Accessibility, affordability and fairness of these mechanisms are pivotal to a person or group to trust and make use of these mechanisms when deemed necessary. Similarly, appropriate forms of compensation for losing rights or access to land and forest, and adequate mechanism for obtaining compensation are important factors for protection of rights hence strengthening tenure security. Other social safeguards such as social capital and networking of the right holders with the powerful actors are also important factors for tenure security. 
Assurance Principles: Processes and Outcomes

Assurance of participation in decisionmaking processes, forest sustainability, and economic security and sustainability are the other key variables that contribute to strengthening tenure security. Trust and confidence on the regulations and institutional arrangements for granting and protecting rights would eventually increase if the respective individuals or groups are involved, or their voices are included in the decision-making processes at various levels related with forest management and benefit distribution. In addition, perception of tenure security would obviously increase when returns of investment of time and other resources is assured, or programs and initiatives of the government and other actors contribute to the improvement of livelihood of right holders. Finally, forest sustainability as an outcome is a strong indicator for expanding tenure security, simply because perception that the supply of the forest products and services in sustenance basis would enhance people's confidence over what rights they have obtained and what efforts they have put for managing forests.

Improvements in statutory tenure regimes do not automatically guarantee sustainable forest management or equitable livelihoods (Larson et al. 2010b). In fact, actors, resource conditions and power dimensions determine the institutional change and resulting impacts on the ground (Mahoney and Thelen 2010; Cleaver 2012).

\section{Forest Tenure Regimes Included in the Special Issue}

Various forest tenure reform regimes in Nepal epitomise a unique and exemplary models of forest rights devolution that integrate some degree of emphasis on both conservation and livelihoods. The diversity of modalities based on specific socio-ecological contexts, management objectives and institutional arrangements has sought to address specific peopleforest relations on the ground. People's participation is sought in most of the forest regimes such as protected areas, conservation zones and government managed forest territories. These modalities offer varying extent of rights and tenure security together with what political space and benefits is provided to the local communities.

Nepal's community forestry is one of the most advanced tenure type and provides local communities with perpetual rights to access, use and manage forest resources under an approved management plan. As compared to other forest management modalities and also compared to collective tenure in many other countries, Nepal's community forestry stands out through stronger transfer of rights (Paudel et al. 2009).

The papers demonstrate that tenure arrangements under each of these modalities have been revised and refined based on adaptive learning gained from tenure reform implementation. As has been described in each paper, there have been several revisions on the law, regulations, guidelines and institutional arrangements and specific practices based on experience gained during implementation. Not all these revisions have been geared towards strengthening tenure security of local communities. Instead, there have been some recurring attempts of limiting the rights of local communities (Shrestha 2001; Mahapatra 2001; Ribot et al. 2006).

It is important to note that the CBFM 
modalities in Nepal have made significant contributions to the environmental, social and economic dimensions. In particular, improved forest condition, biodiversity and ecosystems have been reported (MSFP 2013; DFRS 2015) and these outcomes are mainly attributed to CBFM. Similarly, the growth of thousands of local institutions, strengthening of the local leadership including that of women and other marginalized groups, and spill over effects of these robust local institutions to other aspects of society is often appreciated (Pokhrel et al. 2007; Nightingale and Sharma 2014). Though criticized for limited achievements made against its potential, researches have shown that the forest tenure regimes have also made some contribution to local livelihoods (Thoms 2008; Ojha et al. 2009) and community development (Chapagain and Banjade 2009).

Community forestry has been in place since the last four decades and is considered as the most advanced model in Nepal, which is applied in all the geographical regions of Nepal. Lesson from CF is drawn and scaled out to conservation areas and protected area buffer zones as well. The pro-poor leasehold forestry has a targeted goal of poverty reduction by granting forestland to the selected group of the poor households and allowing them to grow cash crops.

The first paper provides an analysis of community forestry, Nepal's largest, longest, most widespread and perhaps the most advanced forest tenure modality that started in the 1970s. This is applied in all over Nepal. Currently, over one third of Nepal's forest area is under community forestry. Over 19,000 community forest user groups in Nepal are managing about
1.8 million ha of forest, and about one third of Nepal's population is involved in community forestry (DoF 2017). The Master Plan for the Forest Sector 1989 recognised community forestry as a priority program, which was the primary basis for the promulgation of the Forest Act 1993 and Forest Regulations 1995 that define community forestry institution as an autonomous and perpetual entity. Forest Act and Forest Regulations clearly elaborate the rights and obligations of local communities, government forest agencies and other stakeholders; CF guidelines provide the necessary procedures for implementation of the program. Similarly, clearly defined boundary of the rights holders and forest makes community forestry a secure tenure regime. Based on the existing regulations, the District Forest Officers (DFOs) would help in preparing a CFUG constitution, and operational forest management plan (OP), approving the OP, and providing the necessary technical support for forest management. While the law has granted significant rights to local forest users, the rights are often compromised during the development, approval and implementation of the OP. While the CFUGs are considered as autonomous in making their community development plans and plans for mobilizing their fund, the CF guidelines puts additional conditions for allocating their revenue, e.g. at least 25 per cent and 35 per cent revenue ought to be invested in forest conservation/development, and poverty reduction related activities respectively. The existing policies and management practices are often geared towards subsistence use, and reluctance noticed from the part of the government in promoting links of the CF with market. Therefore, CF's full economic potential 
including carbon could not be materialised primarily due to the weak tenure and institutional capacity of both CFUGs and government agencies.

The second paper deals with the collaborative forest management (CFM), which is confined to the large block forests of Terai and Inner-Terai regions. In this scheme, the large tracts of Terai forests are managed by the district forest office in collaboration with local government and respective local communities. The users of these forests are also included from the distant places; many of the CFM groups include users that reside as far as near the Indian border. The District Forest Officer with consultation with the CFM group and other relevant stakeholders prepares a CFM plan, which gets legitimacy once approved by the Department of Forests (DOF). The District Forest Sector Coordination Committee (DFSCC) is the main governing body for CFM. However, the DFO is the de facto manager for the CFM groups having leading role in preparing CFM plans and implementing them on the ground. The groups are involved in implementation of the plans. The income from the CFM is equally distributed between the CFM group and the government. Currently 26 CFM groups covering 0.8 million people are managing 58,000 ha of prime Sal (Shorea robusta) forests of Terai region. Started with the weak legal status based on the guidelines of the Department of Forests, the program is now a part of the Forest Act 1993 (Fifth Amendment 2016). Focus has been given for the 'active' forest management, with major emphasis on managing the commercially valuable Sal species. This regime is new as regulatory frameworks and institutions around the regime are evolving.
The third paper is about the propoor leasehold forestry (LHF) aimed at forest restoration together with poverty reduction. In this modality, forest area is exclusively allocated to the poor households usually organised in small groups of 5-11 households for undertaking agroforestry activities. So far, over 7,000 such groups covering about 65,000 households are managing 42,000 ha of forestlands under the LHF scheme. Agroforestry, non-timber forest products and fodder/grass plantation are some of the key activities to support livelihoods through this scheme. The Forest Act 1993 and Forest Regulations 1995 are the main legal basis for the LHF. As the LHF groups receive only the usufruct rights, they can harness the benefits by planting, raising and harvesting timber and NTFPs from the designated LHF area. The leasehold agreement is made first for 40 years, which can be renewed for another 40 years. The program is criticised for allocating relatively degraded forestland to the poor households, thus termed as 'poor forest for poor people' (Thoms et al. 2006). Tenure security of the LHF groups is normally rated as low since these groups are too weak to exercise and defend their rights. These groups are normally dependent on external agencies for technical support and for financing. In the prevailing condition of the weak support system, LHF is yet to marvel its goal of poverty reduction through forest conservation.

The fourth paper is on buffer zone community forestry (BZ). The main purpose of this regime is to linking conservation with livelihoods. In this scheme, forest areas adjacent to protected areas are handed over to the local community. While this scheme has applied 
the lessons from the $\mathrm{CF}$ in conservation, unlike in CF, CFM or leaseholder forestry regimes, forest product use and trade in this regime is restricted within the buffer zone territory only. Currently over 200 BZ CFUGs are managing forests in buffer zone area, which contains about 0.23 per cent of total forest area in the country. National Park and Conservation Act 1973 (amendment 1993), Buffer Zone Management Regulations 1996 and Buffer Zone Guidelines 1999 have provisions on BZ. While the BZ CF user groups fall directly under buffer zone user committees, it is PA warden who approves, issues a permit and approves reports. The people who are residing within the delineated buffer zone areas can only be the members of the BZ CF. In some cases, this provision has excluded traditional users of particular forest patch (those who are currently outside the BZ boundary). The rights and obligations of the users and the government authorities are not fully elaborated in legal text. In many cases, such rights are negotiated between BZCF members and PA warden. These rights are detailed in OP. Withdrawal is often guided by conservation objectives. Especially caution is taken in permitting timber harvest. Sell of forest products outside buffer zone is restricted. There is a mandatory provision for investing funds $(30-50 \%)$ from PA revenue to the local communities. The paper argues that the pressure on buffer zone community forest because of the increased population is the major challenge for effective BZ management. The fifth paper deals with the protection forests. These forest areas are known for high biodiversity and ecosystem values but are not part of the existing protected area systems. These are managed by the Department of Forest in partnership with local communities. The emphasis is more on biodiversity conservation but also aiming at garnering local support by offering some livelihoods benefits.

The sixth paper describes about Chure conservation, the latest addition of landscape conservation. This is a huge area covering a fragile mountain range that lies between the Mahabharat mountain range and the Terai region of Nepal. The area covers over 12 per cent of the national landmass and 40 per cent of the population and accommodates a combination of tenure types including $\mathrm{CF}, \mathrm{LHF}$ and other modalities. In this region, restrictions on forest use applied. This is one of the highly contested landscapes with strongly divided actors including vibrant grassroots campaigns for and against the chure conservation policy and practice.

The seventh paper on Rangeland governance provides a critical perspective on how local indigenous institutions are being mingled with formal state regulations and institutions in the Rangelands located in the high-mountain areas. The paper highlights that while local/indigenous institutions are gradually becoming less relevant or are vanishing in these remote areas, there is weak presence of the modern state institutions. Therefore, the area is largely in an institutional vacuum. However, the area is of high significance to highland indigenous people who have limited alternative livelihoods options. Multiple Acts have provision on Rangeland Governance such as Forest Act 1993, Local Self Governance Act 1999 and Pastureland Nationalization Act 1974 adding complexity by making several authority structures with overlapping jurisdictions. The concerned DFO in case 
of government managed forests, Chief Warden of the National Parks and Wildlife Reserves and the concerned intuitions in case of community based forestry (CF, LHF, BZ CF and Conservation Areas) hold an authority to issue grazing rights to range lands, whereas the National Rangeland Development Policy, 2011 has recognised the concerned VDCs as the authority of issuing grazing rights and managing rangelands in their territories. While there is a clear division of authorities and responsibilities between state agencies, forest user groups and individuals within a particular tenure regime, there exists an overlapping jurisdiction between central government agencies and local governments. The National Rangeland Policy (2012) has provision for establishing various rangeland management institutions including Rangeland Users Committee involving traditional rangeland users; policy has not been implemented yet because of lack of needed legal and regulatory instruments. Except issuing permits to individual herders there is no clear mechanism for granting collective rights or recognizing traditional rights and institutions. Similarly, both the Forestry and Livestock sector doesn't have effective plans and implementation mechanism for sustainable management of rangeland.

The eighth paper by Amatya and Lamsal provides the current status of private forests in Nepal. Private forests are forests grown in the privately owned land and are registered with the District Forest Office. Forest Act 1993, Forest Regulations 1995 and Private Forest Development Directives 2011 have specific provisions on private forest. DFO (PA wardens in case of buffer zone) is authorized to register and issue permits for forest products harvesting and transportation. Other key features of private forest include: the owner of the private forests holds the right of access, withdrawal, management, exclusion and alienation; compensation is provided to the forest owner in case of acquisition of land or removal of products from private forest; and generally, forest owners can make decisions regarding growing, extracting and selling forest products but the government can impose certain restrictions (e.g. choice of species, harvesting practice, etc in buffer zone). While clear legal and institutional provisions for a private forest exist, transaction costs are considered to be considerably high during the registration as well as in harvesting and transportation of forest products from these forests.

The final paper is on 'gender and social inclusion across forest tenure regimes in Nepal', which provides the comparison across five prominent community based forest tenure regimes in Nepal, namely community forest, pro-poor leasehold forest, collaborative forest, buffer zone community forest and conservation areas. The paper assesses whether, and to what extent, these regimes have recognized and provisioned for specific rights of women in policies and practices by adding the feminist institutionalist approach.

\section{Key Insights and Way Forward}

While Nepal's forest tenure reforms are hailed for its scale and effectiveness in terms of conserving otherwise denuded hills of Nepal, a number of bottlenecks persist that require additional attention for the success of these reforms. The key issues at the national policy are: inadequate consultative processes, diverse and competing interest among key actors, unpredictability of policies and 
regulations hampering tenure security, and limited political will of major actors in strengthening forest tenure security. Presence of the strong civil society, positive popular sentiment towards forest rights devolution, and strong lobby for community based forestry has been persistently resisting the regressive moves of the government in limiting community rights (Paudel et al. 2012). At the subnational or meso-level, challenges are related to the knowledge and attitude of the frontline service providers e.g., limited awareness on tenure; different perception of tenure arrangements by the regime; limited skills of social mobilisation and other support to local communities; limited linkages with national level; lack of clear incentive for reform implementation; their belief system different than demanded for community-based forestry; poor cognizance of technical aspects of forest management; technology use, etc. Similarly, at the community level a number of issues need attention. The issues include social diversity and differentiation, unequal and discriminatory social structures, highly demanding bureaucratic procedures (technical management, documentation, etc), limited resources, limited access to market information; limited capital for investment for value addition, lack of access to technology, limited access to administrative and technical service provisioning, etc.

Key reflection from the discourse around forest tenure reform can be summarized as following:

Differences exist between national policy arena and forest tenure reform implementation on the ground. While national policy and regulatory frameworks are considered as supportive of devolving rights and community empowerment, practices on the ground are fraught with institutional red tape and narrow bureaucratic interests, often skewing the rights of local communities over forests during planning and implementation of the plans.

Noticeable differences found across various tenure regimes in terms of bundle of rights. CF modality appears to be the most advanced in case of exercise of management rights and autonomy to use forest products. Leasehold forestry is also strong in terms of bundle of rights but exercise of those rights is largely dependent on external support which often compromises their ability to bargain. The protection forest seems to be the weakest modality. This is also a new modality which is yet to be fully implemented to examine its implications on outcomes.

Differences are also evident across modalities with regard to liveliboods outcomes. While MOFSC has endorsed 'forestry for prosperity' as the long term vision, it has not been adequately translated into the regulations, programs and plans. Leasehold forestry is the only modality which exclusively deals with the poverty reduction agenda and offers privileged priority to livelihoods of the poor. In terms of contribution to livelihoods, CF and buffer zone probably fare best as they have a relatively longer history of reform implementation and institutional arrangements are adapted to channel benefit streams to their member households.

Subsistence orientation and barriers to commercial management appear to be the key features of community based forestry. Across various tenure regimes, tenure reform implementation has largely limited to subsistence use of forest products and 
appears to be discouraging for commercial management, trade, sell and transportation particularly when exported outside the groups.

Achieving social inclusion and equity is still a distant goal. Local heterogeneity and unequal power relationships are not adequately addressed by most of the reform regimes. In the case of community forestry, some attempts have been made to increase political representation in decision-making forums, and specific provisions for equitable benefit sharing. Other regimes such as CFM, Chure, Rangeland and protected areas are either gender blind or have not seriously considered gender issues in decisionmaking and benefit distribution.

Community-based forest management modalities contributed positively in climate change mitigation. The regions that have CBFM as a dominant mode of forest management have shown increased forest cover and quality than regions with less forest area under CBFM. Deforestation and forest degradation is found high in Chure region where there are very few CBFM groups, whereas forest increment and corresponding carbon sink is highest in middle hills after massive CF program launched (DFRS 2015).

CBFM institutions are becoming effective vehicles for climate change adaptation initiatives. Most of the donors, government agencies and NGOs have been using CBFM groups as the window for implementing climate change adaptation related initiatives (Nightingale 2013; MSFP 2016). As robust and perhaps the only democratically functioning local institutions, CBFM groups attracted the attention of the support agencies. Many considered that strengthening CBFM institutions would add value as these groups have not only been implementing forest management activities but also leading many other activities that fall under various other sectors such as livelihoods and poverty reduction, community infrastructure development, education, health, conflict resolution, networking, soil conservation, river bank management and so on (Pokharel et al. 2007).

Similarly, there is little or no formal recognition of the role of local government. Local government's role is either completely ignored (as in the case of CF, BZCF and LHF) or marginalised (in the case of CFM). As Nepal's sectoral restructuring is underway in line with the newly promulgated Constitution of 2015, there are at least two dominant narratives polarised for and against the role of local governments in forest management. The first narrative, led by the forest bureaucrats, is for centralized control over forests with the rationale that many forest territories are not aligned with the political boundary of the local municipalities, and that forests have externalities and inter-scale linkages (upstream-downstream, environmental services, etc.) that cross the boundary of single governance level. They also argue that the local municipalities might attempt to exercise power in local forest governance, hence the CBFM groups might lose the rights they have already been enjoying. The other narrative, largely led by the pro-CF actors, is for giving authority to local municipalities in relation with registering, supporting and monitoring CBFM related tasks. They critique the centralized tendency of the forest bureaucracy as they conspire the narrow personal interests of the bureaucrats in opposing the role of local governments. As federal system has yet to be fully 
implemented, and related deliberations are highly contested, it requires more research, analysis, dialogue and experimentation in order to aligning forest tenure reform with the new constitution. The forest tenure reforms also need to take note of the changing local context and dynamics migration, remittance economy, decreased availability of labour, and their impacts on people-forest relations.

\section{REFERENCES}

Chapagain, N. and Banjade, M.R. 2009. Community Forestry and Local Development: Experiences from the Koshi Hills of Nepal. Journal of Forest and Livelihood, 8(2): 78-92.

Cleaver, F. 2012. Development through Bricolage: Rethinking Institutions for Natural Re-source Management. New York: Routledge.

Colfer, C.J.P. and Capistrano, D. (Eds.). 2005. The Politics of Decentralization: Forests, People and Power. London, UK: Earthscan.

DFRS. 2015. State of Nepal's Forests. Forest Resource Assessment (FRA) Nepal. Department of Forest Research and Survey (DFRS), Government of Nepal, Kathmandu, Nepal.

DoF. 2017. Hamro Ban. Annual Report of the Department of Forest. 2073/2074. Department of Forest, Government of Nepal, Kathmandu, Nepal.

FAO. 2011. Reforming Forest Tenure: Issues, Principles and Process. Rome: Food and Agriculture Organization of the United Nations.

Larson, A.M., Barry, D., Dahal, G.R. and Colfer, C.J.P. (Eds.). 2010a. Forests for People: Community Rights and Forest Tenure Reform. London: Earthscan.

Larson, A.M., Barry, D. and Dahal, G.R. 2010b. Introduction. In: A.M. Larson, D. Barry, G.R. Dahal and C.J.P. Colfer (Eds.), Forests for People: Community Rights and Forest Tenure Reform. London: Earthscan.

Mahapatra, R. 2001. Betrayed: Nepal's Forest Bureaucracy Prepares for the Funeral of the Much Hailed Community Forest Management Programme. Down to Earth, 9.
Mahoney, J. and Thelen, K. (Eds.). 2010. Explaining Institutional Change: Ambiguity, Agency and Power. New York: Cambridge University Press.

MSFP. 2016. Results, Good Practices and Lesson Learnt from MSFP. The Multi-stakeholder Forestry Programme, Kathmandu, Nepal.

MSFP. 2013. Persistence and Change: Thirty Years of Community Forestry in Nepal. The Multistakeholder Forestry Program, Kathmandu, Nepal.

Mwangi, E. and Meinzen-Dick, R. 2009. Understanding Property Rights in Land and Natural Resource Management. In: J. Kirsten, A. R. Dorward, C. Poulton, and N. Vink (Eds.), Institutional Economics Perspectives on African Agricultural Development. Washington DC: International Food Policy Research Institute.

Nightingale, A. and Sharma, J.R. 2014. Conflict Resilience among Community Forestry User Groups: Experiences in Nepal. Disasters, 38(3): 517-539.

Nightingale, A.J. 2009. Warming up the Climate Change Debate: A Challenge to Policy based on Adaptation. Journal of Forest and Livelihood, 8(1): 84-89

North, D.C. 2005. Institutions and the Performance of Economies Over Time. In: C. Menard and M.M. Shirley (Eds.), Handbook of New Institutional Economics. Dordrecht: Springer.

Ojha, H., Persha, L. and Chhatre, A. 2009. Community Forestry in Nepal: A Policy Innovation for Local Livelihoods. IFPRI Discussion Paper, International Food Policy Research Institute, Washington DC, USA.

Paudel, N.S., Banjade, M.R. and Dahal, G.R. 2009. Community Forestry in Changing Context: Emerging Market Opportunities and Tenure Rights. ForestAction and CIFOR, Kathmandu, Nepal.

Paudel, N., Monterroso, I. and Cronkleton, P. 2012. Secondary Level Organisations and the Democratisation of Forest Governance: Case Studies from Nepal and Guatemala. Conservation and Society, 10(2): 124-135.

Pokharel, B., Branney, P., Nurse, M. and Malla, Y. 2007. Community Forestry: Conserving Forests, Sustaining Livelihoods and Strengthening Democracy. Journal of Forest and Livelihood, 6(2): 8-19. 
Ribot, J.C., Agrawal, A. and Larson A.M. 2006. Recentralizing While Decentralizing: How National Governments Reappropriate Forest Resources. World Development, 34(11): 18641886.

Ribot, J.C. and Larson, A.M. (Eds.). 2005. Democratic Decentralisation through a Natural Resources Lens. London: Routledge.

RRI. 2014. What Future for Reform? Progress and Slowdown in Forest Tenure Reform since 2002. Rights and Resources Initiative, Washington DC, USA.

Safitri, M.A. 2015. Assessing Tenure Security of Land and Forestry Rights of Indigenous Peoples and other Forest Communities in Indonesian Legal Framework. Final Report, CIFOR, Bogor, Indonesia.

Schlager, E. and Ostrom, E. 1992. Property-rights Regimes and Natural Resources: A Conceptual Analysis. Land Economics, 68: 249-62.
Shrestha, N.K. 2001. The Backlash: Recent Policy Changes Undermine User Control of Community Forests in Nepal. Forest, Trees and People Newsletter, 44: 62-65.

Sjaastad, E. and Bromley, D.W. 2000. The Prejudices of Property Rights: On Individualism, Specificity, and Security in Property Regimes. Development Policy Review, 18: 365-389.

Thoms, C.A., Karna, B. and Karmacharya, M.B. 2006. Limitations of Leasehold Forestry for Poverty Alleviation in Nepal. Society and Natural Resources, 19(10): 931-938.

Thoms, C.A. 2008. Community Control of Resources and the Challenge of Improving Local Livelihoods: A Critical Examination of Community Forestry in Nepal. Geoforum, 39(3): 1452-1465.

von Benda-Beckmann, F., von Benda-Beckmann, K. and Wiber, M. 2006 Changing Properties of Property. New York and London: Berghahn Books. 